\title{
Hubungan Kecerdasan Emosional terhadap Hasil Belajar Anak Usia Dini
}

\author{
Anisa Nurdiyanti ${ }^{1}$, Yuyun Yulianingsih ${ }^{2}$, Syamiyah ${ }^{3}$ \\ ${ }^{1}$ PAUD Tahfidz Alquran Yamabi, Klender, Jakarta Timur \\ 2, 3Universitas Islam Negeri Sunan Gunung Djati Bandung \\ Jl. Cimencrang, Cimenerang, Gedebage, Kota Bandung, Jawa Barat \\ Email: anisanurdiyanti@gmail.com¹, yuyunyulianingsih67@gmail.com², \\ ade.syamiyah@yahoo.com³
}

\begin{abstract}
Abstrak
Penelitian ini bertujuan untuk mengetahui hubungan kecerdasan emosional terhadap hasil belajar anak usia dini pada aspek perkembangan sosial emosional usia 5-6 tahun. Penelitian ini menggunakan metode dan pendekatan kuantitatif korelasional. Subjek penelitian ini adalah kelompok B di salah satu RA di Kota Bandung yang berjumlah 46 anak. Penelitian ini menggunakan sampel jenuh, yang berarti semua populasi dijadikan sampel. Teknik pengumpul data melalui lembar observasi. Hasil analisis data penelitian menggunakan perhitungan koefisien korelasi Spearman Rank memperoleh hasil $\rho_{\text {hitung }}$ sebesar 0,74. Sedangkan, hasil perhitungan uji signifikansi korelasi menggunakan t test diperoleh nilai thitung sebesar 7,33 dan taraf signifikansi $5 \%$ dengan $\mathrm{db}=44$ adalah 2,017. Maka, $t_{\text {hitung }}=7,33>t_{\text {tabel }}=2,017$, dan dapat diinterpretasikan bahwa terdapat hubungan yang signifikan antara kecerdasan emosional dengan hasil belajar anak usia dini. Selain itu, koefisien determinasi yang diperoleh sebesar 55\%. Artinya, kecerdasan emosional memberikan kontribusi sebanyak 55\% terhadap hasil belajar anak usia dini di salah satu RA di Kota Bandung.
\end{abstract}

Kata kunci: anak usia dini, hasil belajar, kecerdasan emosional, perkembangan, sosial emosional

\begin{abstract}
This study aims to determine the relationship of emotional intelligence in early childhood learning outcomes on aspects of emotional social development aged 5-6 years. This study uses quantitative correlational methods and approaches. The subject of this study was group $B$ in one RA in Bandung City which amounted to 46 children. This study uses saturated samples, which means that all populations are sampled. Data collection techniques through observation sheets. The results of the analysis of research data
\end{abstract}


using the calculation of the Spearman Rank correlation coefficient obtained a result of $\rho_{\text {count }}$ of 0.74 . Meanwhile, the results of the calculation of the significance of the correlation test using t-test obtained the value of $t_{\text {count }}$ of 7.33 and a significance level of $5 \%$ with $d b=44$ is 2.017. So, $t_{\text {count }}=7.33>t_{\text {table }}=2.017$, and can be interpreted that there is a significant relationship between emotional intelligence and early childhood learning outcomes. In addition, the determination coefficient obtained is 55\%. That is, emotional intelligence contributes as much as 55\% of the results of early childhood learning in one RA in the city of Bandung.

Keywords: early childhood, emotional intelligence, development, learning outcomes, social-emotional

\section{Pendahuluan}

Pendidikan Anak Usia Dini sebagaimana tercantum dalam UU RI Nomor 20 Tahun 2003 tentang Sistem Pendidikan Nasional Bab I Pasal I Ayat 14, yaitu

suatu upaya pembinaan yang ditujukan kepada anak sejak lahir sampai dengan usia 6 tahun yang dilakukan melalui pemberian rangsangan pendidikan untuk membantu pertumbuhan dan perkembangan jasmani dan rohani anak agar anak memiliki kesiapan dalam memasuki pendidikan lebih lanjut.

Berdasarkan pengertian tentang pendidikan anak usia dini menurut UU RI Nomor 20 Tahun 2003, maka usia dini (golden age) adalah fase yang cocok untuk menanamkan kecerdasan emosional. Hal itu dikarenakan, masa golden age ini hanya terjadi satu kali dalam perkembangan kehidupan, sekaligus masa yang kritis bagi kehidupan anak.

Kecerdasan emosional adalah kemampuan menata perasaan (emosi) diri, serta kemampuan memahami dengan spontan kebutuhan atau perasaan orang lain. Sedangkan, Hasnida (2014:144) mengungkapkan

kecerdasan emosional adalah kemampuan merasakan, memahami dan secara efektif menerapkan daya dan kepekaan emosi sebagai sumber energi, informasi dan pengaruh yang manusiawi. Substansi dari kecerdasan emosional adalah kemampuan merasakan dan memahami untuk kemudian disikapi secara manusiawi. Orang yang EQ-nya baik, dapat memahami perasaan orang lain, dapat membaca yang tersurat dan yang tersirat, dapat menangkap bahasa verbal dan non verbal.

Bahkan, Salovey menempatkan kecerdasan pribadi Gardner sebagaimana dikutip Goleman (1999:57-59) dalam definisi dasar tentang kecerdasan emosional yang dicetuskannya, seraya memperluas kemampuan ini menjadi lima wilayah utama, yaitu 
mengenali emosi diri, mengelola emosi, memotivasi diri sendiri, mengenali emosi orang lain, dan membina hubungan.

Jamaris (2014:102) mengatakan bahwa salah satu karakteristik anak yang mengalami kesulitan emosi adalah memperoleh hasil belajar di bawah kemampuan akademik yang dimilikinya. Karena menurut Meier sebagaimana dikutip Khodijah (2014:143), emosi berpengaruh besar pada kualitas dan kuantitas belajar. Emosi yang positif dapat mempercepat proses belajar dan mencapai hasil belajar yang lebih baik, sebaliknya emosi yang negatif dapat memperlambat belajar atau bahkan menghentikannya sama sekali.

Hasil belajar merupakan wujud pencapaian peserta didik; sekaligus merupakan lambang keberhasilan pendidik dalam membelajarkan peserta didik (Yusuf, 2015:181). Sedangkan, Sukmadinata (2011: 102-103) mengungkapkan:

Hasil belajar atau achievement merupakan realisasi atau pemekaran dari kecakapan-kecakapan potensial atau kapasitas yang dimiliki seseorang. Penguasaan hasil belajar oleh seseorang dapat dilihat dari perilakunya, baik perilaku dalam bentuk penguasaan pengetahuan, keterampilan berpikir maupun keterampilan motorik. Hampir sebagian terbesar dari kegiatan atau perilaku yang diperlihatkan seseorang merupakan hasil belajar.

Istilah hasil belajar tidak terlepas dari istilah penilaian. Wahyudin \& Agustin (2011:51) mengungkapkan:

Dalam upaya pendidikan, istilah penilaian merupakan istilah yang sudah tidak asing lagi. Dalam praktiknya, penilaian merupakan bagian integral dari proses belajar mengajar secara keseluruhan (sistem intruksional) yang tidak dapat dipisahkan dari komponen lainnya. Penilaian dalam konteks pembelajaran di Pendidikan Anak Usia Dini (PAUD) adalah prosedur sistematis yang digunakan untuk mendapatkan informasi tentang kinerja dan atau kemajuan berbagai aspek perkembangan.

Menurut pendapat ahli di atas mengenai penilaian dalam konteks pembelajaran di PAUD, maka keberhasilan belajar pada penelitian ini difokuskan pada aspek perkembangan sosial emosional usia 5-6 tahun.

Berdasarkan studi pendahuluan yang dilakukan di salah satu RA di Kota Bandung, terdapat 21 anak yang kurang berkembang terkait hasil belajar anak usia dini pada aspek perkembangan sosial emosional. Permasalahan yang ditemukan terkait hasil belajar anak usia dini pada aspek perkembangan sosial emosional, diantaranya beberapa anak tidak mandiri dan selalu ditemani orangtua saat kegiatan belajar berlangsung, sifat dan sikap anak yang temperamental, sifat anak yang sensitif (mudah 
menangis karena ibunya tidak menemani di sekolah), mudah tersinggung, dan tidak percaya diri terhadap kemampuan dirinya.

Kecerdasan emosional adalah salah satu hal krusial yang harus ditumbuhkembangkan sejak usia dini. Mengingat pentingnya kecerdasan emosional dikembangkan sejak usia dini demi menunjang keberhasilan belajar anak usia dini, maka tujuan penelitian ini adalah untuk mengetahui realitas kecerdasan emosional, realitas hasil belajar anak usia dini (aspek perkembangan sosial-emosional usia 5-6 tahun), dan hubungan kecerdasan emosional terhadap hasil belajar anak usia dini.

\section{Metodologi}

Penelitian ini menggunakan metode kuantitatif korelasional. Metode kuantitatif korelasional bertujuan untuk mengetahui sejauh mana variasi dalam suatu faktor atau karakteristik berhubungan dengan variasi dalam faktor atau karakteristik lainnya (Maolani \& Cahyana, 2015:78). Populasi pada penelitian ini adalah siswa/i Kelompok B di salah satu RA di Kota Bandung yang berjumlah 46 orang. Penelitian ini menggunakan teknik sampling jenuh, yang berarti semua populasi dijadikan sampel.

Teknik pengumpulan data pada penelitian ini adalah observasi untuk memperoleh data kecerdasan emosional dan hasil belajar anak usia dini (aspek perkembangan sosial emosional usia 5-6 tahun), serta didukung dengan dokumentasi. Instrumen penelitian yang digunakan adalah lembar observasi. Data kecerdasan emosional diperoleh dari pengisian lembar observasi yang terdiri dari 5 indikator, yaitu mengenali emosi diri, mengelola emosi, memotivasi diri sendiri, mengenali emosi orang lain, dan membina hubungan. Adapun jumlah pernyataan sebanyak 17 item. Sedangkan, data hasil belajar anak usia dini diperoleh dari pengisian lembar observasi yang terdiri dari 3 indikator, yaitu kesadaran diri, rasa tanggung jawab untuk diri sendiri dan orang lain, serta perilaku prososial. Adapun jumlah pernyataan sebanyak 10 item.

Analisis data pada penelitian ini menggunakan analisis parsial untuk mengetahui skor tiap variabel dan analisis korelasi dengan perhitungan koefisien korelasi Spearman Rank untuk mengetahui tingkat hubungan antara dua variabel. Lalu selanjutnya dilakukan uji signifikansi korelasi menggunakan "t test". Langkah terakhir, dilakukan perhitungan koefisien determinasi untuk mengetahui kontribusi atau sumbangan yang diberikan oleh sebuah variabel atau lebih $\mathrm{X}$ (bebas) terhadap variabel $\mathrm{Y}$ (terikat). 


\section{Hasil dan Pembahasan}

Berdasarkan hasil penelitian dari lembar observasi, diperoleh data tentang kecerdasan emosional dan hasil belajar anak usia dini yang ditunjukkan pada tabel 1.

Tabel 1. Data Kecerdasan Emosional dan Hasil Belajar Anak Usia Dini

\begin{tabular}{cccccc}
\hline Nama Anak & Skor KE & Skor HB & Nama Anak & Skor KE & Skor HB \\
\hline AR & 50 & 30 & BL & 46 & 26 \\
AD & 48 & 27 & DK & 50 & 28 \\
DF & 51 & 29 & NL & 58 & 33 \\
DV & 45 & 28 & AL & 55 & 32 \\
JR & 66 & 39 & SY & 54 & 31 \\
ES & 51 & 30 & TS & 52 & 30 \\
KZ & 51 & 27 & AS & 48 & 27 \\
MV & 55 & 37 & AY & 46 & 27 \\
NV & 45 & 28 & AN & 52 & 29 \\
NK & 51 & 30 & DN & 51 & 28 \\
RH & 51 & 30 & FR & 49 & 29 \\
RS & 53 & 39 & HD & 46 & 31 \\
FZ & 53 & 29 & KY & 49 & 28 \\
AZ & 47 & 29 & MS & 45 & 28 \\
Al & 48 & 28 & WD & 48 & 28 \\
AV & 54 & 30 & NR & 49 & 29 \\
FD & 49 & 27 & NS & 54 & 31 \\
FT & 58 & 31 & RZ & 51 & 31 \\
HK & 45 & 27 & SB & 51 & 30 \\
JM & 52 & 29 & SF & 47 & 28 \\
NZ & 50 & 29 & SL & 44 & 24 \\
GS & 57 & 31 & ZE & 49 & 28 \\
AF & 46 & 28 & RF & 47 & 25 \\
\hline
\end{tabular}

Berdasarkan analisis data yang sudah ditentukan, dilakukan analisis parsial untuk menjawab submasalah nomor 1 dan 2. Sedangkan untuk submasalah nomor 3 dilakukan analisis korelasi. Berikut ini akan diuraikan pengolahan data berdasarkan rumusan masalah.

Tabel 2. Rekapitulasi Skor Rata-rata Variabel Kecerdasan Emosional

\begin{tabular}{lcc}
\hline \multicolumn{1}{c}{ Indikator } & Skor & Interpretasi \\
\hline Mengenali Emosi Diri & 4,06 & Baik \\
Mengelola Emosi & 3,66 & Baik \\
Memotivasi Diri Sendiri & 3,64 & Baik \\
Mengenali Emosi Orang Lain & 3,91 & Baik \\
Membina Hubungan & 3,84 & Baik \\
\hline
\end{tabular}

Berdasarkan Tabel 2, untuk mengetahui skor rata-rata variabel kecerdasan emosional, dilakukan perhitungan $\frac{4,06+3,66+3,64+3,91+3,84}{5}=\frac{19,11}{5}=3,82$. Nilai tersebut berada pada skala 3,40 - 4,19 dengan interpretasi baik. Artinya, realitas kecerdasan emosional pada Kelompok B di salah satu RA di Kota Bandung berkualifikasi baik. Emosi memainkan peran yang sedemikian penting dalam kehidupan, maka penting diketahui 
bagaimana perkembangan dan pengaruh emosi terhadap penyesuaian pribadi dan sosial (Hurlock, 1978:210). Menurut Davis (2012:41), kecerdasan emosional yang tinggi mencakup pemahaman diri, kontrol diri, ketekunan, motivasi diri yang tinggi, altruisme, dan empati dalam jumlah besar. Semua adalah keterampilan yang seharusnya diajarkan kepada anak. Orang dengan kecerdasan emosional yang tinggi bisa membaca perasaan dan emosi orang lain. Mereka menangani hubungan dengan baik.

Tabel 3. Rekapitulasi Skor Rata-rata Variabel Hasil Belajar Anak Usia Dini

\begin{tabular}{lcc}
\hline \multicolumn{1}{c}{ Indikator } & Skor & Interpretasi \\
\hline Kesadaran Diri & 2,82 & Baik \\
$\begin{array}{l}\text { Rasa Tanggung Jawab untuk Diri Sendiri } \\
\text { dan Orang Lain }\end{array}$ & 2,92 & Baik \\
Perilaku Prososial & 3,004 & Baik \\
\hline
\end{tabular}

Berdasarkan Tabel 3., untuk mengetahui skor rata-rata variabel hasil belajar anak usia dini, dilakukan perhitungan $\frac{2,82+2,92+3,004}{3}=\frac{8,74}{3}=2,91$. Nilai tersebut berada pada skala 2,1 - 3 dengan interpretasi baik. Artinya, realitas hasil belajar anak usia dini pada Kelompok B di salah satu RA di Kota Bandung berkualifikasi baik. Hasil belajar atau achievement merupakan realisasi atau pemekaran dari kecakapan-kecakapan potensial atau kapasitas yang dimiliki seseorang. Penguasaan hasil belajar oleh seseorang dapat dilihat dari perilakunya, baik perilaku dalam bentuk penguasaan pengetahuan, keterampilan berpikir maupun keterampilan motorik. Hampir sebagian terbesar dari kegiatan atau perilaku yang diperlihatkan seseorang merupakan hasil belajar (Sukmadinata, 2011:102-103). Hasil belajar anak usia dini tidak terlepas dari upaya mengoptimalkan aspek perkembangannya, yaitu nilai agama dan moral, fisik-motorik, kognitif, bahasa, sosial-emosional, dan seni.

Selanjutnya dilakukan pengujian normalitas pada distribusi untuk kedua variabel. Pengujian normalitas pada variabel kecerdasan emosional diperoleh nilai chi kuadrat $\left(X^{2}\right)$ hitung $=6,94$ dan chi kuadrat $\left(X^{2}\right)$ tabel $=7,815$ dengan $\mathrm{db}=3$ pada taraf signifikansi $5 \%$. Karena $X^{2}$ hitung $=6,94<X^{2}$ tabel $=7,815$, maka data tentang variabel kecerdasan emosional berdistribusi normal. Sedangkan, pengujian normalitas pada variabel hasil belajar anak usia dini diperoleh nilai chi kuadrat $\left(x^{2}\right)$ hitung $=25,14$ dan chi kuadrat $\left(x^{2}\right)$ tabel $=7,815$ dengan $\mathrm{db}=3$ pada taraf signifikansi $5 \%$. Karena $X^{2}$ hitung $=25,14>X^{2}$ tabel $=$ 7,815 , maka data tentang variabel hasil belajar anak usia dini berdistribusi tidak normal. Maka, dapat disimpulkan bahwa salah satu dari kedua data variabel $X$ dan $Y$ berdistribusi tidak normal. 
Selain itu, untuk pengujian linieritas regresi diperoleh hasil $F_{\text {hitung }}$ sebesar 0,59 dan $F_{\text {tabel }}$ dengan taraf signifikansi $5 \%$ pada $d b \frac{17}{27}=2,01$. Karena $F_{\text {hitung }}=0,59<F_{\text {tabel }}=2,01$, maka dapat diinterpretasikan bahwa regresi $Y$ atas $X$ linier. Maka, berdasarkan teknik analisis data yang sudah ditentukan, penelitian ini akan menggunakan statistik nonparametrik dengan perhitungan koefisien korelasi Spearman Rank dan memperoleh hasil nilai $\rho_{\text {hitung }}$ sebesar 0,74 . Untuk mengetahui kekuatan hubungan, hasil $\rho_{\text {hitung }}$ yang diperoleh sebesar 0,74 ini berada pada nilai korelasi 0,60-0,799 (kuat), sehingga dapat diketahui bahwa kecerdasan emosional dan hasil belajar anak usia dini memiliki tingkat hubungan kuat yang ditunjukkan pada tabel 4.

Tabel 4. Tingkat Korelasi dan Kekuatan Hubungan

\begin{tabular}{ccc}
\hline No. & Nilai Korelasi $(\mathbf{r})$ & Tingkat Hubungan \\
\hline 1. & $0,00-0,199$ & Sangat lemah \\
2. & $0,20-0,399$ & Lemah \\
3. & $0,40-0,599$ & Cukup \\
4. & $0,60-0,799$ & Kuat \\
5. & $0,80-0,100$ & Sangat kuat \\
\hline
\end{tabular}

Sumber: Siregar, 2013

Selanjutnya, dilakukan uji signifikansi koefisien korelasi menggunakan "t test" dengan rumus:

$$
\begin{aligned}
t_{\text {hitung }} & =\frac{\rho \sqrt{\mathrm{N}-2}}{\sqrt{1-\rho^{2}}} \\
& =\frac{0,74 \sqrt{46-2}}{\sqrt{1-(0,74)^{2}}} \\
& =\frac{4,91}{\sqrt{0,45}} \\
& =\frac{4,91}{0,67}=7,33
\end{aligned}
$$

Harga thitung tersebut selanjutnya dibandingkan dengan $t_{\text {tabel. }}$ Untuk menentukan harga $t_{\text {tabel}}$, terlebih dahulu menentukan derajat kebebasan dengan rumus:

$\mathrm{db}=\mathrm{N}-2=46-2=44$

$t_{\text {tabel }}$ pada taraf signifikansi 5\% dengan $\mathrm{db}=44$ (interpolasi) adalah 2,017.

Ketentuan interpretasi atau pengujian signifikansi koefisien korelasi adalah sebagai berikut: 
a. Jika $t_{\text {hitung }}>t_{t a b e l}$, maka hipotesis alternatif $(\mathrm{Ha})$ diterima dan hipotesis nol $(\mathrm{Ho})$ ditolak. Dengan kata lain, ada hubungan yang signifikan antara variabel $\mathbf{X}$ dengan variabel Y.

b. Jika $t_{\text {hitung }}<t_{\text {tabel, }}$ maka hipotesis nol $(\mathrm{Ho})$ diterima dan hipotesis alternatif $(\mathrm{Ha})$ ditolak. Dengan kata lain, tidak ada hubungan yang signifikan antara variabel $X$ dan variabel $\mathrm{Y}$.

Karena harga $t_{\text {hitung }}=7,33>t_{\text {tabel }}=2,017$, maka Ha diterima dan dapat diinterpretasikan bahwa terdapat hubungan yang signifikan antara kecerdasan emosional dengan hasil belajar anak usia dini.

Pengujian terakhir yaitu menentukan koefisien determinasi untuk mengetahui kontribusi atau sumbangan yang diberikan kecerdasan emosional terhadap hasil belajar anak usia dini dengan rumus:

$$
\begin{aligned}
K D & =\rho^{2} \times 100 \% \\
& =0,74^{2} \times 100 \% \\
& =0,55 \times 100 \%=\mathbf{5 5} \%
\end{aligned}
$$

Berdasarkan hasil yang diperoleh di atas, dapat dikatakan bahwa kecerdasan emosional memberikan kontribusi sebanyak 55\% terhadap hasil belajar anak usia dini. Sedangkan sisanya sebesar $45 \%$ dipengaruhi oleh variabel lain yang tidak menjadi bagian dalam penelitian ini.

Meier sebagaimana dikutip Khodijah (2014:143) mengatakan bahwa emosi berpengaruh besar pada kualitas dan kuantitas belajar. Emosi yang positif dapat mempercepat proses belajar dan mencapai hasil belajar yang lebih baik, sebaliknya emosi yang negatif dapat memperlambat belajar atau bahkan menghentikannya sama sekali. Penjelasan tentang hal ini dapat diambil dari teori Otak Triune. Menurut teori ini, otak manusia terdiri dari tiga bagian dan pemanfaatan seluruh bagian otak dapat membuat belajar lebih cepat, lebih menarik, dan lebih efektif. Dari ketiga bagian otak tersebut, bagian otak yang memainkan peran dalam belajar adalah neokorteks, sedangkan yang memainkan peran besar dalam emosi adalah sistem limbik. Jika siswa mengalami emosi positif, maka sel-sel saraf akan mengirimkan impuls-impuls positif ke neokorteks dan proses belajar pun dapat terjadi. Sebaliknya, jika siswa mengalami emosi negatif, maka tertutup kemungkinan untuk timbulnya impuls-impuls yang mendorong belajar, tetapi yang terjadi adalah meningkatnya fungsi mempertahankan diri 
terhadap emosi yang tidak menyenangkan. Akibatnya, proses belajar menjadi lamban atau bahkan terhenti.

Kecerdasan emosi perlu diasah sejak dini, karena kecerdasan emosi merupakan salah satu poros keberhasilan individu dalam berbagai aspek kehidupan. Kemampuan anak mengembangkan kecerdasan emosinya, berkolerasi positif dengan keberhasilan akademis, sosial, dan kesehatan mentalnya. Anak yang memiliki kecerdasan emosi tinggi identik dengan anak yang bahagia, bermotivasi tinggi, dan mampu bertahan dalam menjalani berbagai kondisi stres yang dihadapi (Mashar, 2011:65-66). Selain itu, Davis (2012:41) memperkuat dengan mengungkapkan bahwa kecerdasan emosional yang tinggi mencakup pemahaman diri, kontrol diri, ketekunan, motivasi diri yang tinggi, altruisme, dan empati dalam jumlah besar. Semua adalah keterampilan yang seharusnya diajarkan kepada anak. Orang dengan kecerdasan emosional yang tinggi bisa membaca perasaan dan emosi orang lain. Mereka menangani hubungan dengan baik.

\section{Penutup}

Berdasarkan hasil penelitian yang dilakukan pada Kelompok B di salah satu RA di Kota Bandung, dapat disimpulkan bahwa terdapat hubungan kecerdasan emosional terhadap hasil belajar anak usia dini. Selain itu, ada beberapa saran yang dapat menjadi bahan pertimbangan bagi pihak-pihak yang bersangkutan, diantaranya sebagai berikut:

1. Bagi pendidik, diharapkan untuk memahami dan memiliki kemampuan dalam hal pengembangan kecerdasan emosional. Hal ini dikarenakan pengembangan kecerdasan emosional pada usia dini akan sangat berpengaruh terhadap hasil belajar anak.

2. Bagi sekolah, diharapkan dapat memberikan fasilitas untuk mengembangkan kecerdasan emosional anak sehingga diperoleh hasil belajar yang optimal.

3. Bagi mahasiswa Program Studi Pendidikan Islam Anak Usia Dini yang memiliki ketertarikan ingin meneliti variabel yang sama, sebaiknya terlebih dahulu mengkaji hasil-hasil penelitian yang sudah ada atau dari hasil penelitian sebelumnya, agar penelitian tersebut dapat menghasilkan temuan-temuan baru yang nantinya akan saling melengkapi dengan temuan-temuan sebelumnya dan juga dapat menjadi perbandingan bagi penelitian selanjutnya. 


\section{Daftar Pustaka}

Davis, G. A. (2012). Anak Berbakat \& Pendidikan Keberbakatan. (A. Cahayani, Penerj.) Jakarta: Indeks.

Goleman, D. (1999). Emotional Intelligence. (T. Hermaya, Penerj.) Jakarta: Gramedia Pustaka Utama.

Hasnida. (2014). Analisis Kebutuhan Anak Usia Dini. Jakarta: Luxima Metro Media.

Hurlock, E. B. (1978). Perkembangan Anak Jilid 1 (6 ed.). (A. Dharma, Penyunt., M. Tjandrasa, \& M. Zarkasih, Penerj.) Jakarta: Erlangga.

Jamaris, M. (2014). Kesulitan Belajar (Perspektif, Asesmen, dan Penanggulangannya). Bogor: Ghalia Indonesia.

Khodijah, N. (2014). Psikologi Pendidikan. Depok: Rajagrafindo Persada.

Maolani, R., \& Cahyani, U. (2015). Metodologi Penelitian Pendidikan. Jakarta: Raja Grafindo Persada.

Mashar, R. (2011). Emosi Anak Usia Dini dan Strategi Pengembangannya. Jakarta: Kencana Prenada Media.

Republik Indonesia. (2003). Undang-undang Republik Indonesia Nomor 20 Tahun 2003 tentang Sistem Pendidikan Nasional.

Siregar, S. (2013). Metode Penelitian Kuantitatif (Dilengkapi dengan Perbandingan Perhitungan Manual \& SPSS). Jakarta: Kencana Prenada Media.

Sukmadinata, N. S. (2011). Landasan Psikologi Proses Pendidikan. Bandung: Remaja Rosdakarya.

Wahyudin, U., \& Agustin, M. (2011). Penilaian Perkembangan Anak Usia Dini (Panduan untuk Guru, Tutor, Fasilitator dan Pengelola Pendidikan Anak Usia Dini). Bandung: Refika Aditama.

Yusuf, M. (2015). Asesmen dan Evaluasi Pendidikan (Pilar Penyedia Informasi dan Kegiatan Pengendalian Mutu Pendidikan). Jakarta: Prenada Media Group.

\section{Biodata Penulis}

Anisa Nurdiyanti lahir di Bekasi pada 20 Maret 1996, telah menyelesaikan pendidikan S1 di Fakultas Tarbiyah dan Keguruan UIN Sunan Gunung Djati Bandung (2018).

Yuyun Yulianingsih lahir di Bandung pada 01 Januari 1967, telah menyelesaikan pendidikan S1 di Fakultas Tarbiyah IAIN Sunan Gunung Djati Bandung (1990), S2 Program Studi Pendidikan Umum di Universitas Pendidikan Indonesia (2008), dan sedang melanjutkan S3 Program Studi Pendidikan Islam UIN Sunan Gunung Djati 
Bandung (2015). Penulis merupakan dosen tetap Program Studi Pendidikan Islam Anak Usia Dini Fakultas Tarbiyah dan Keguruan UIN Sunan Gunung Djati Bandung. Bidang khusus yang ditekuni penulis saat ini adalah Metodologi Pendidikan.

Syam'iyah lahir di Bekasi pada 11 Juli 1977, telah menyelesaikan pendidikan S1 di Fakultas Tarbiyah IAIN Sunan Gunung Djati Bandung (2001), S2 Program Studi Pendidikan Bahasa Arab di UIN Sunan Gunung Djati Bandung (2007), dan sedang melanjutkan S3 di UIN Sunan Gunung Djati Bandung. 